\title{
Vertical migration behaviour in the larvae of the shore crab Carcinus maenas from a microtidal system (Gullmarsfjord, Sweden)
}

\author{
Henrique Queiroga ${ }^{1, *}$, Per-Olav Moksnes ${ }^{2}$, Sónia Meireles ${ }^{1}$ \\ ${ }^{1}$ Departamento de Biologia, Universidade de Aveiro, Campus Universitário de Santiago, 3810-193 Aveiro, Portugal \\ ${ }^{2}$ Kristineberg Marine Research Station, 45034 Fiskebäckskil, Sweden
}

\begin{abstract}
Tide-related vertical migration behaviours which assist in horizontal transport of marine larvae have been documented in many species from meso-tidal systems; however, little is known about larval behaviour in areas where the tides do not produce predictable changes in water currents. We assessed the vertical migration behaviour in larvae of the shore crab Carcinus maenas (L.) from the Swedish west coast, to explore possible transport mechanisms in a micro-tidal system. Replicated plankton samples were collected at a fixed station from 2 depths during flood and ebb tides, and analysed for effects of tides and light on temporal and vertical patterns in abundance. In a complementary experiment, first-stage zoeae were hatched in the laboratory from field-collected females and studied in constant darkness for endogenous circa-tidal or circa-diel rhythms. The abundance of different larval stages decreased from the first to the fourth zoeal stage by a factor 10, whereas megalopal densities were similar to those of the first zoea. This pattern in abundance indicates an offshore/onshore transportation of larvae during ontogeny, suggesting a behavioural component in larval dispersal. However, contrary to what has been demonstrated in larvae from meso-tidal areas, none of the larval stages displayed a vertical or temporal pattern in abundance related to the tide, although a clear semi-diurnal tidal change of approximately $0.3 \mathrm{~m}$ was registered throughout the sampling periods. Instead, the highest densities of all larval stages were consistently sampled during low light conditions, indicating a diel pattern in swimming behaviour. This behaviour appears to be controlled by exogenous cues, since the laboratory experiment with first zoeae in constant darkness did not indicate any consistent tidal or diel rhythm in vertical migration. The lack of an endogenous circa-tidal vertical migration rhythm suggests that Swedish shore crabs are reproductively isolated from the British Isles populations, where this behaviour has been demonstrated to be inherited. The possibility that C. maenas larvae in micro-tidal systems may use predictable sea and land breezes as a mechanism for cross-shelf transport is discussed.
\end{abstract}

KEY WORDS: Larvae - Vertical migration - Rhythms · Exogenous cues $\cdot$ Tides · Light · Dispersal

Resale or republication not permitted without written consent of the publisher

\section{INTRODUCTION}

Vertical movements by larvae of invertebrate and fish species is a common phenomenon of great ecological importance. Vertical movements potentially assist in processes that control survival and the supply of

*E-mail: hqueiroga@bio.ua.pt larvae to juveniles' habitats such as foraging behaviour, predator avoidance and dispersal by currents (for reviews see Forward 1976, 1988, Chia et al. 1984, Norcross \& Shaw 1984, Sulkin 1984, Young \& Chia 1987, Boehlert \& Mundy 1988, Young 1995). In many instances, vertical movements of larvae are synchronised to the diel or the tidal cycles, which are the most pervasive and predictable short-term environmental cycles in the marine environment. Although the ulti- 
mate causes responsible for the development of these behaviours are not always easy to identify, vertical migration on a background of a cyclic environment has adaptive advantages. In these cases of cyclic vertical migration, the onset, extent and termination of the ascent phase can be controlled by (1) an endogenous clock with a free-running period similar to the period of the environmental cycle; (2) external stimuli associated with the environmental cycle; or (3) a combination of both factors (Forward 1988). During the last 2 decades, it has become increasingly evident that the interaction between larval swimming behaviour and currents is paramount to the control of dispersal and supply of competent larvae to habitats suitable for settlement and post-larval development. Data in support of this conclusion have been found in different taxonomic groups and also in very different oceanic settings (e.g. Phillips 1981, Cronin \& Forward 1982, Fortier \& Leggett 1983, Willis \& Oliver 1990, Bingham \& Young 1991, Zeng \& Naylor 1996a,b, Queiroga et al. 1997). Besides synchronous migration related to diel and tidal cycles, ontogenic differences in average depth distribution also contribute to species-specific

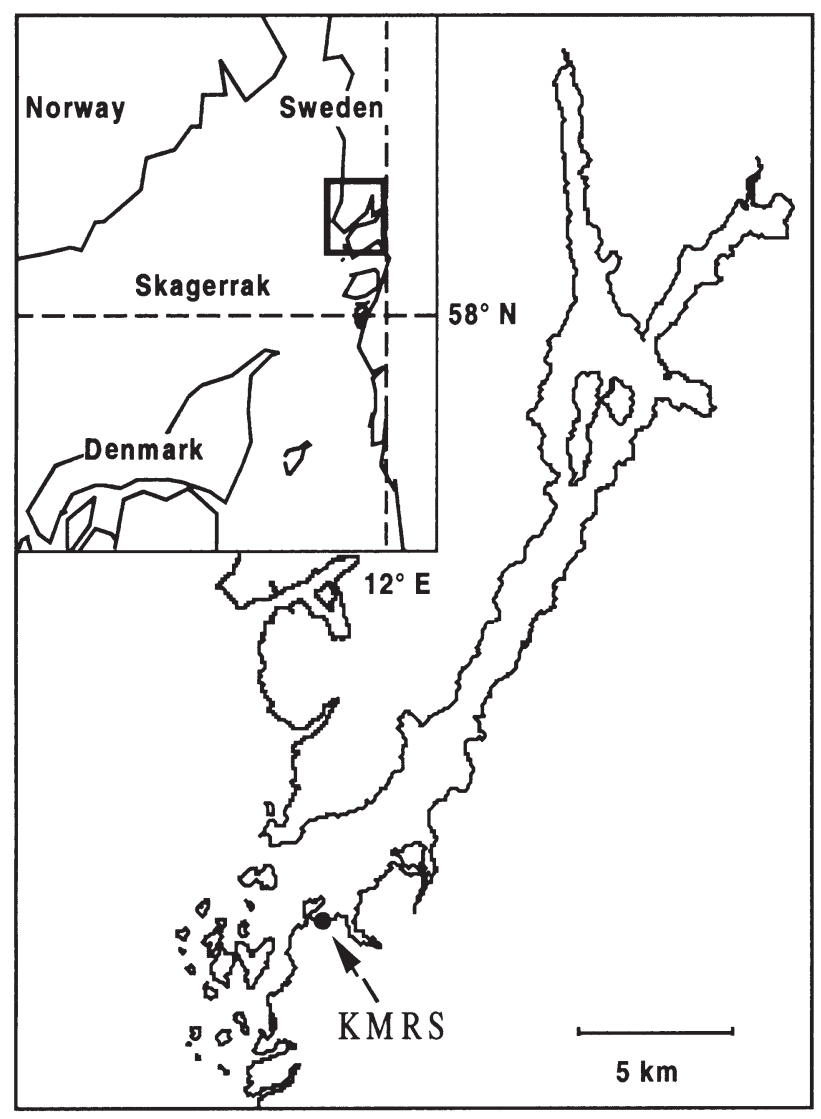

Fig. 1. Location of the Gullmarsfjord (western Sweden) and Kristineberg Marine Research Station (KMRS), where the field samples were taken modes of dispersion (Shanks 1995). Most studies assessing vertical migration of marine larvae are from meso-tidal $(2 \mathrm{~m}<$ tidal range $<4 \mathrm{~m})$ temperate systems. Throughout the temperate zone, the phase duration and the amplitude of the light:dark cycle does not vary much during the larval season. However, large areas like the Mediterranean, large parts of the Gulf of Mexico and the SE part of the North Sea are dominated by micro-tidal conditions, where tides do not produce predictive changes of hydrostatic pressure or of water currents. Little is known about larval behaviour and their adaptations to cyclic forcing agents in these small-amplitude tidal systems.

The portunid crab Carcinus maenas (L.) stands amongst the most characteristic and successful crustaceans that inhabit European estuaries and coastal waters. Its natural range extends from $70^{\circ} \mathrm{N}$ in Norway to $22^{\circ} \mathrm{N}$ in Mauritania and includes Iceland, the Faroe Islands, the Skagerrak and Kattegat and the British Islands (Udekem d'Acoz 1999). A closely related form, Carcinus aestuarii (Nardo), occurs in the Mediterranean (Udeken d'Acoz 1999). Throughout its range of distribution, Carcinus lives in very different tidal conditions: the Skagerrak, Kattegat and Mediterranean, for instance, have tidal ranges in the order of $0.2 \mathrm{~m}$, whereas maximum vertical range of the tide in some locations of the English Channel exceeds $9 \mathrm{~m}$. In mesotidal estuaries and coastal areas from Portugal (Queiroga et al. 1994) and Wales (Zeng \& Naylor 1997), Carcinus maenas first zoeae hatch during ebb tides. Newly hatched larvae are dispersed seawards by selective tidal stream transport, where the zoea larvae migrate vertically to the surface during ebb and close to the bottom during flood tides. Since currents are slower close to the bottom due to friction, this behaviour will result in a horizontal transport of the larvae towards the sea (Zeng \& Naylor 1996a,c, Queiroga et al. 1997). The behaviour is under endogenous control (Zeng \& Naylor 1996a,c, Duchêne \& Queiroga 2001). Moreover, it appears to be inherited, i.e. this behaviour occurs even in larvae that were never subjected to tidal influences during embryonic and ontogenic developments (Zeng \& Naylor 1996d). Available evidence suggests that larvae develop in shelf waters (Rees 1955, Roff et al. 1986, Lindley 1987, Queiroga 1996) over 4 to 10 wk depending on temperature (Dawirs 1985, Mohamedeen \& Hartnoll 1989, Nagaraj 1993). The megalopa is the stage that reinvades estuaries. It also displays a circatidal vertical migration rhythm in meso-tidal areas, but in the opposite phase compared to zoea larvae (Zeng \& Naylor 1996b, Queiroga 1998). This rhythm results in a high number of megalopae in surface waters during flood tides, particularly at night, and a selective tidal stream transport towards the shore and up estuaries (Queiroga et al. 1994, Zeng \& Naylor 1996b). However, 
in the megalopal stage, the migration behaviour appears not to be endogenously controlled, but may result from the inhibition of swimming activity, and concurrent sinking to the bottom, by chemical cues present in estuarine waters as has been described for other brachyurans (Forward \& Rittschof 1994). Furthermore, inhibition of swimming activity may be overridden by the rise in hydrostatic pressure and salinity that occurs during flood (Zeng \& Naylor 1996b, Queiroga 1998).

Although vertical migration appears to play an important role in the dispersal and recruitment of shore crabs in meso-tidal systems, nothing is known about vertical migration behaviour of Carcinus larvae from systems where tidal currents do not play a significant role in water movements. The present study was set up to examine vertical migration behaviour of Carcinus maenas larvae from the Swedish west coast, where tide range is normally less than $0.3 \mathrm{~m}$. The specific questions that will be addressed here are: (1) Does vertical distribution of first zoeae and megalopae in the field change according to phase of tide? (2) Does vertical distribution of first zoeae and megalopae in the field change according to phase of day? And (3) is there any evidence of an endogenous vertical migration rhythm of circa-tidal period in laboratory-hatched first zoeae? Since an endogenous circa-tidal rhythm appears to be inherited in shore crabs from meso-tidal areas (Zeng \& Naylor 1996d), an answer to Question 3 would also provide indirect evidence as to whether Swedish and British shore crabs are reproductively isolated.

\section{MATERIALS AND METHODS}

Field study - effect of tidal phase and light conditions on vertical distribution. To assess the vertical migration behaviour in shore crab larvae, 2 short field studies were conducted outside a shallow bay next to Kristineberg Marine Research Station, located in the Gullmarsfjord on the Swedish west coast $\left(56^{\circ} 15^{\prime} \mathrm{N}\right.$, $11^{\circ} 35^{\prime} \mathrm{E}_{\text {; Fig. }}$ 1). The Baltic current affects this area, and summer surface salinity and temperature normally range from 15 to 30 and 15 and $20^{\circ} \mathrm{C}$, respectively. The Baltic current creates a pycnocline that is generally found at 15 to $20 \mathrm{~m}$ depth with higher salinity water underneath (Svansson 1984). Tides in the area are semidiurnal with small amplitude, normally $<0.3 \mathrm{~m}$ (Moksnes \& Wennhage 2001). Alternation of spring and neap tides is also a clear feature of the tidal regime, with average ranges of ca. 0.4 and $0.2 \mathrm{~m}$, respectively. However, variation of seawater level due to other factors such as wind or atmospheric pressure is greater than variation due to the state of the tide. Shallow bays in the Gullmarsfjord serve as nursery areas for shore crabs (Eriksson \& Edlund 1977, Phil \& Rosen- berg 1982) and the water exchange to these bays is driven mainly by density differences (baroclinic circulation), wind and large-scale currents along shore, whereas tides are thought to play a negligible role (Andersson \& Rahm 1985, Söderkvist 1997).

To assess how water column abundance of shore crab larvae (zoeal stages and megalopae) varied temporally in relation to tidal phase and light conditions at 2 different depths, two $3 \mathrm{~d}$ field studies were conducted from 4 to 7 and from 11 to 14 August 1998. Plankton samples were collected from a floating pier, moored approximately $10 \mathrm{~m}$ above the bottom. We used 2 gasoline-driven centrifugal pumps, each delivering approximately $0.25 \mathrm{~m}^{3} \mathrm{~min}^{-1}$, to obtain simultaneous samples from both 1 and $9 \mathrm{~m}$ (1 m above bottom) depths (hereafter referred to as 'surface' and 'bottom samples'). Pumps have been used in other sampling programmes designed to address similar problems (Cronin \& Forward 1979, Queiroga et al. 1994), and appear to provide estimates of decapod larvae density comparable to plankton nets (Queiroga 1995). Water was pumped for $10 \mathrm{~min}$ for each replicate and sieved through 2 partially submerged $250 \mu \mathrm{m}$ plankton nets. Three replicate samples were consecutively taken from both depths, at each sampling time. To estimate the water volume sampled, flow rate of the pumps was calculated before and after each sampling time by recording the time taken to fill a known volume of water. Samples were taken approximately $2 \mathrm{~h}$ after every expected high and low tide in each $3 \mathrm{~d}$ period, resulting in 4 distinct tidal/light periods being sampled each day, which showed the opposite phase in the 2 sampling periods. In the first sampling period, nightflood, dawn-ebb, day-flood and evening-ebb were sampled, and in the second period night-ebb, dawnflood, day-ebb and evening-flood were assessed. By contrasting the results from the 2 sampling periods, we would potentially be able to separate tidal and light effects on larval distribution. Samples were preserved in $96 \%$ alcohol immediately after collection. Carcinus maenas larval stages were identified and counted under a stereomicroscope, following the descriptions given by Rice \& Ingle (1975), and counts were standardised to number of larvae $\mathrm{m}^{-3}$. Vertical profiles of salinity and temperature were obtained for each sampling moment with a hand-held CTD (ADM, Standard Probe C16). Water level and light intensity (PAR) were continuously measured at Kristineberg Marine Research Station during the extent of both sampling periods.

To analyse the effect of tidal and light phases on the vertical and temporal distribution of shore crab larvae in each sampling period, larval densities were tested as the dependent variables in 3-factor ANOVA models with light/tidal phase (4 levels as described above), 
depth (surface and bottom) and day (Days 1 to 3) as independent variables. Analyses were performed separately on the densities of Zoea 1, Zoeae 2 to 4 (which had densities too low to be analysed separately) and megalopae. To better separate effects of light and tides

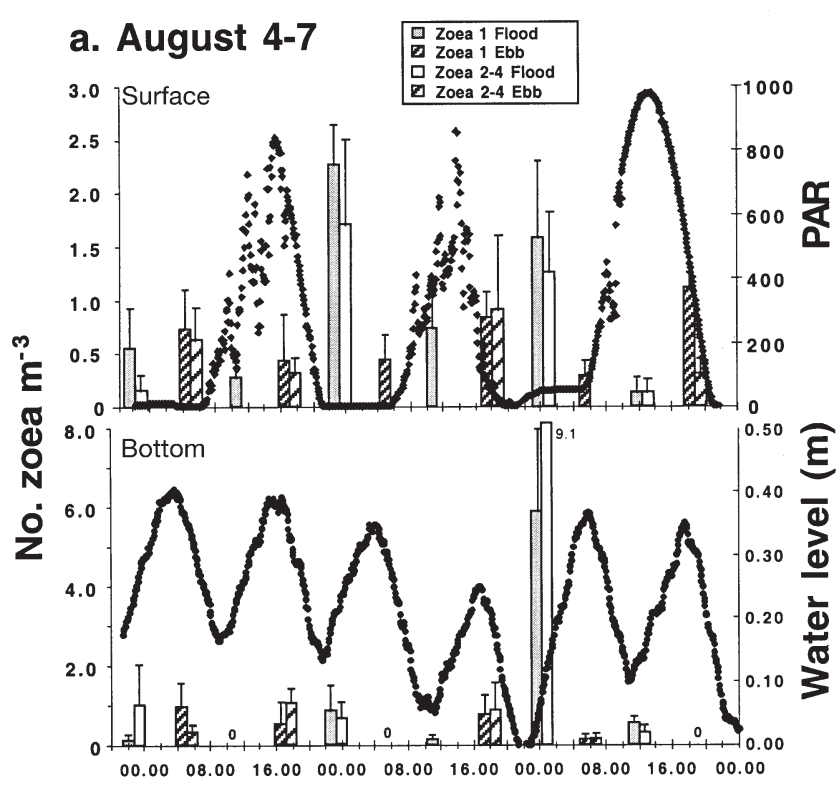

b. August 11-14

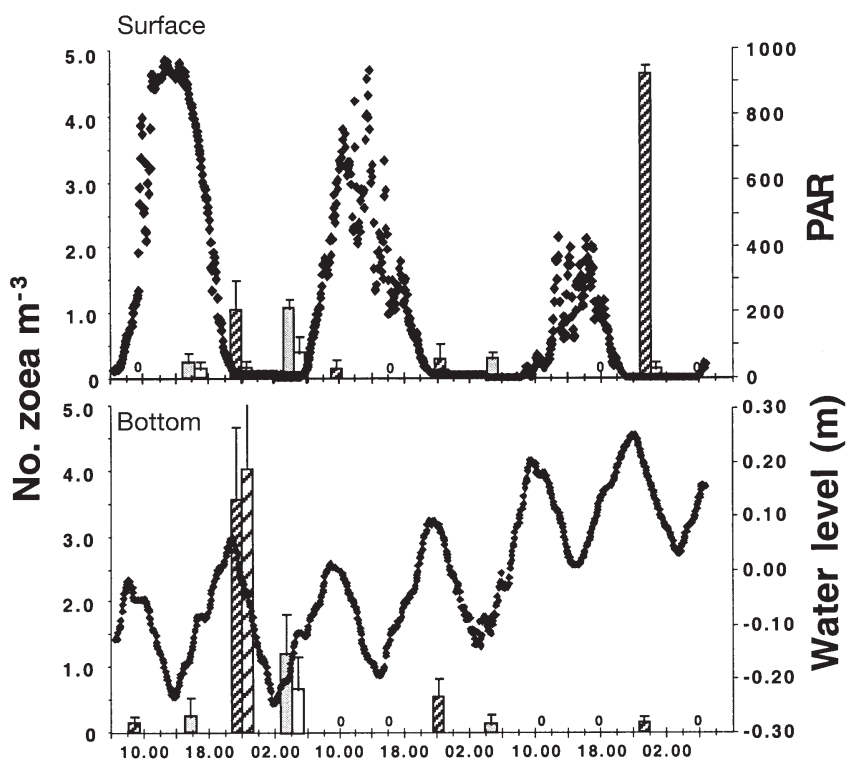

Time

Fig. 2. Carcinus maenas zoeae. Mean number of Zoea 1 and Zoeae 2 to 4 larvae (+1 SE) collected approximately $2 \mathrm{~h}$ after expected high and low waters for a total of $3 \mathrm{~d}$ on (a) 4 to 7 August and (b) 11 to 14 August 1998. Top parts of graphs show number of larvae collected at surface and the variation in light intensity (PAR). Lower parts of graphs show number of larvae collected concurrently at the bottom and tidal fluctuations in water level. PAR and water level are shown by dots on larval abundance, we performed complementary analyses for each larval group where we pooled our 4 light phases into just high or low light conditions, so that dusk to dawn samples represented low light conditions and morning to evening samples represented high light conditions. This allowed us to test tide (ebb and flood), light (low and high) and depth (surface and bottom) in an orthogonal, 3-factor ANOVA model using data from both sampling periods together. All data were tested for homoscedasticity with Cochran's $C$-test (Sokal \& Rohlf 1969) and number of larvae $10 \mathrm{~m}^{-3}$ was $\log (x+1)$-transformed to meet the assumption of homogenous variance. A posteriori multiple comparisons were carried out with the StudentNewman Keuls (SNK) procedure.

Because our sampling times were fixed following the tides, the light conditions at each tidal phase changed slightly from day to day also within each sampling period, resulting in a less exact test of the effect of light. To further assess the effect of light intensity on larval abundance, we performed linear regression analyses using light intensity (PAR) measured for each replicate sample as the independent variable and larval density as the dependent variable in 3 separate analyses for each larval stage group, using data from both sampling periods and depths together. Correlation analyses were performed between the 3 larval stage groups using data from both sampling periods. To evaluate any possible effect of density stratification on vertical distribution of larvae, a stratification index was calculated as:

$$
\sigma_{t}=\frac{\sigma_{\text {bottom }, t}-\sigma_{\text {surface }, t}}{Z_{t}}
$$

where $\sigma$ is calculated from the salinity and temperature values by the equations given by Fofonoff \& Millard (1983), $Z$ represents depth and $t$ each sampling time.

Laboratory experiment-endogenous rhythms of first zoea. To assess if laboratory-hatched first zoea from Sweden displayed any endogenous vertical migration rhythms, a laboratory experiment was performed at Kristineberg Marine Research Station. Since one aim of this study was to compare the behaviour of Swedish larvae with that of larvae from meso-tidal areas, we tried to mimic the experimental set-up used by Zeng \& Naylor (1996a-d) as much as possible. Ten ovigerous females were collected near the fjord and kept in the laboratory with running seawater, under a natural light:dark cycle, until hatching. The females were not subjected to variation in hydrostatic pressure. Vertical migration behaviour of recently hatched first zoeae was studied in constant conditions, in the dark, in a room keep at $18^{\circ} \mathrm{C}$. After hatching, 1 batch of 1500 to 3200 zoeae from each of 10 females was placed in a 
$50 \times 15 \times 5 \mathrm{~cm}$ Perspex chamber. Water was renewed by a continuous flow of seawater from a header tank, at a rate of ca. $150 \mathrm{ml} \mathrm{h}^{-1}$, which entered the chamber close to the bottom. An overflow was placed at a height of $40 \mathrm{~cm}$ from the bottom, protected with a mesh to prevent loss of larvae. This low flow rate did not disturb the vertical movements of the larvae. Two paper frames of identical size were attached to the chamber, one just bellow the surface and the other just above the bottom, and 2 video cameras, connected to time-lapse VCRs, recorded the larvae through the windows. Date and time of day were automatically recorded on the tapes by the VCRs. Infrared illumination, which is invisible to decapod larvae (Forward \& Costlow 1974), was provided laterally by a row of lamps. The zoeae were not fed during the experiments. Usually, less than $1 \mathrm{~d}$ elapsed between hatching and the start of each experiment, which lasted until all larvae were dead, although in 2 cases the experiment started on the third day after hatching. Due to the time needed to count all the larvae that were recorded on tape, the zoeae were sub-sampled by placing a mask with 12 apertures over the windows and counting only the larvae seen through the apertures. Moreover, counting was made during periods of $20 \mathrm{~s}$ at discrete time intervals of 15 min. The number of zoeae at the surface and bottom was separately analysed using auto-correlation analyses. This experimental design is similar to the one used by Zeng \& Naylor (1996a-d), except that these authors used an actograph that integrated counts over periods of $15 \mathrm{~min}$.

\section{RESULTS}

\section{Field study - vertical distribution and effect of tidal phase and light conditions}

\section{Sea level and water column stratification}

A clear semi-diurnal oscillation of the tide at the fjord was detected during Sampling Periods 1 (4 to 7 August, Fig. 2) and 2 (11 to 14 August, Fig. 3), with average ranges of 0.3 and $0.2 \mathrm{~m}$, respectively. It is noteworthy that average sea level during Period 1 was about $0.25 \mathrm{~m}$ above hydrographical 0 , while it was $0.05 \mathrm{~m}$ below that level during Period 2, indicating a change that was not due to the effect of tides. Only small vertical differences of temperature and salinity were observed during the sampling periods, suggesting that the bottom samples were also taken above the pycnocline in the fjord. Only 3 times in 24 sampling moments did bottom temperature exceed surface temperature by more than $1^{\circ} \mathrm{C}$. Bottom salinity exceeded surface salinity by more than 1 in 4 out of 24 occasions. The stratification index estimates were, therefore, generally below 0.1 and had little effect on larval distribution.

All 4 zoeal stages and the megalopa of the shore crab were collected during both $3 \mathrm{~d}$ sampling periods

\section{a. August 4-7}

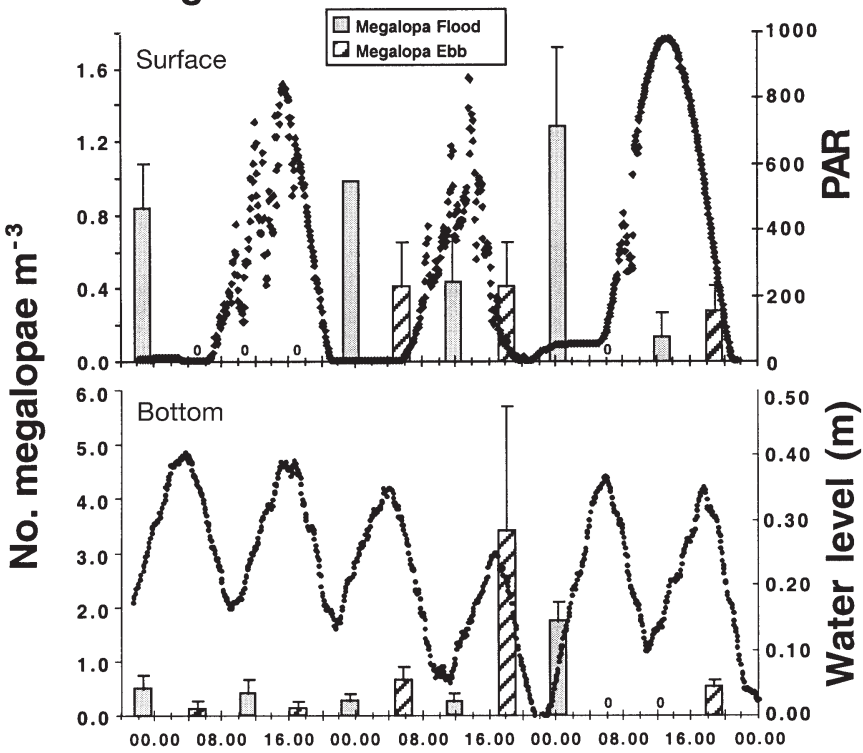

\section{b. August 11-14}

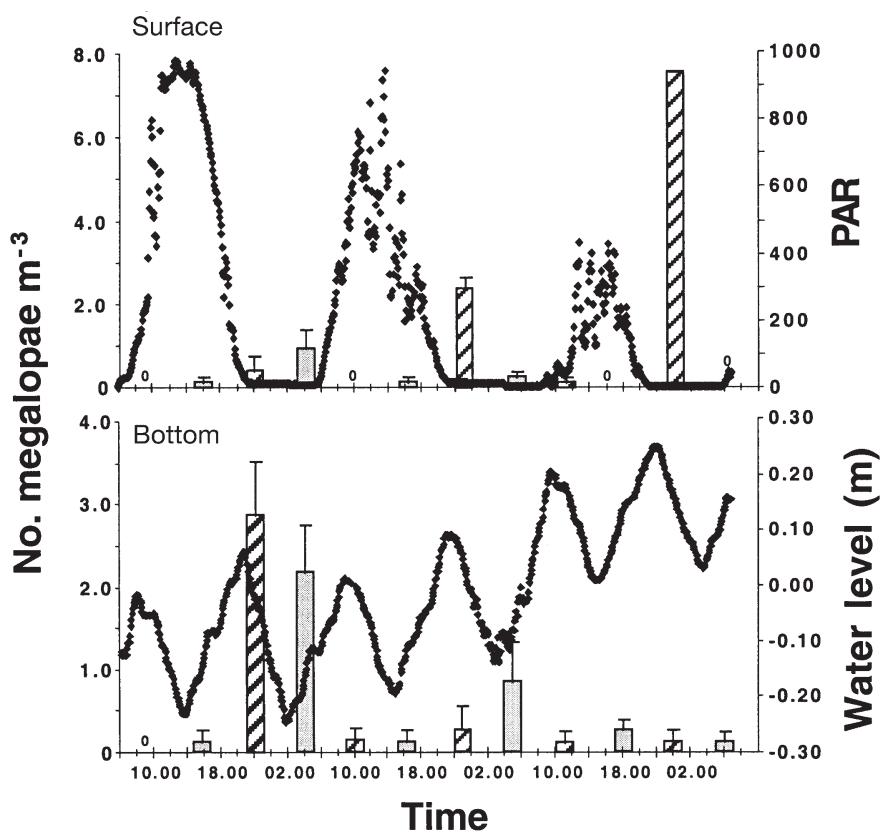

Fig. 3. Carcinus maenas. Mean number of megalopae (+1 SE) collected ca. $2 \mathrm{~h}$ after expected high and low waters for a total of $3 \mathrm{~d}$ on (a) 4 to 7 August and (b) 11 to 14 August 1998. Top parts of graphs show number of larvae collected at the surface and the variation in light intensity (PAR). Lower parts of graphs show number of larvae collected concurrently at the bottom and tidal fluctuations in water level. PAR and water level are shown by dots 
Table 1. Carcinus maenas, field experiments. Summary of 3-way ANOVA models for Sampling Periods 1 (4 to 7 August) and 2 (11 to 14 August) and both periods together (4 to 14 August). $\log (x+1)$-transformed number of Zoea 1, Zoeae 2 to 4 and megalopae larvae per $10 \mathrm{~m}^{3}$ as a function of light-tidal phase (Sampling Period 1: night-flood, dawn-ebb, day-flood, evening-ebb; Sampling Period 2: night-ebb, dawn-flood, day-ebb, evening-flood), Depth (surface, bottom) and Day (1 to 3), or as a function of tidal phase (ebb, flood), light (low, high intensity) and depth for the 2 sampling periods together. ${ }^{*} \mathrm{p}<0.05_{i}{ }^{* *} \mathrm{p}<0.01_{i}{ }^{* * *} \mathrm{p}<0.001$;

${ }^{* * * *} \mathrm{p}<0.0001$; ns: $\mathrm{p}>0.05, \mathrm{~ns}^{1}: \mathrm{p}>0.01$

\begin{tabular}{|c|c|c|c|c|c|c|c|}
\hline \multirow{2}{*}{$\begin{array}{l}\text { Dependent variable: } \\
\text { source of variation }\end{array}$} & \multirow[t]{2}{*}{ df } & \multicolumn{2}{|c|}{ Zoea 1} & \multicolumn{2}{|c|}{ Zoeae 2 to 4} & \multicolumn{2}{|c|}{ Megalopae } \\
\hline & & SS & $F$ & SS & $F$ & $\mathrm{SS}$ & $F$ \\
\hline \multicolumn{8}{|l|}{4 to 7 August } \\
\hline Light-tidal phase (A) & 3 & 3.38 & $5.57^{* *}$ & 6.74 & $14.5^{* * * *}$ & 4.30 & $11.3^{* * * *}$ \\
\hline Depth (B) & 1 & 1.05 & $5.19^{*}$ & 0.12 & $0.75 \mathrm{~ns}$ & 0.26 & $2.02 \mathrm{~ns}$ \\
\hline Day (C) & 2 & 0.91 & $2.26 \mathrm{~ns}$ & 0.36 & $1.16 \mathrm{~ns}$ & 1.84 & $7.27^{* *}$ \\
\hline $\mathrm{A} \times \mathrm{B}$ & 3 & 0.22 & $0.37 \mathrm{~ns}$ & 0.14 & $0.31 \mathrm{~ns}$ & 0.91 & $2.40 \mathrm{~ns}$ \\
\hline $\mathrm{A} \times \mathrm{C}$ & 6 & 3.81 & $3.14^{*}$ & 5.85 & $6.28^{* * * *}$ & 3.12 & $4.11^{* *}$ \\
\hline $\mathrm{B} \times \mathrm{C}$ & 2 & 0.58 & $1.43 \mathrm{~ns}$ & 0.41 & $1.34 \mathrm{~ns}$ & 0.04 & $0.16 \mathrm{~ns}$ \\
\hline $\mathrm{A} \times \mathrm{B} \times \mathrm{C}$ & 6 & 3.08 & $2.54^{*}$ & 1.97 & $2.11 \mathrm{~ns}$ & 1.13 & $1.48 \mathrm{~ns}$ \\
\hline Residual & 48 & 9.71 & 7.46 & 6.08 & & & \\
\hline \multicolumn{8}{|l|}{11 to 14 August } \\
\hline Light-tidal phase (A) & 3 & 7.64 & $27.7^{* * * *}$ & 1.22 & $7.75^{* * *}$ & 7.56 & $17.5^{* * * *}$ \\
\hline Depth (B) & 1 & 0.13 & $1.37 \mathrm{~ns}$ & 0.10 & $1.89 \mathrm{~ns}$ & 0.00 & $0.01 \mathrm{~ns}$ \\
\hline Day (C) & 2 & 3.39 & $18.4^{* * * *}$ & 2.31 & $22.0^{* * * *}$ & 0.25 & $0.86 \mathrm{~ns}$ \\
\hline$A \times B$ & 3 & 0.09 & $0.34 \mathrm{~ns}$ & 0.46 & $2.92 \mathrm{~ns}^{1}$ & 2.03 & $4.71^{* *}$ \\
\hline $\mathrm{A} \times \mathrm{C}$ & 6 & 2.43 & $4.41^{* *}$ & 1.79 & $5.68^{* * *}$ & 2.71 & $3.13^{*}$ \\
\hline $\mathrm{B} \times \mathrm{C}$ & 2 & 0.79 & $4.30^{*}$ & 0.39 & $3.76 \mathrm{~ns}^{1}$ & 1.46 & $5.06^{*}$ \\
\hline $\mathrm{A} \times \mathrm{B} \times \mathrm{C}$ & 6 & 2.98 & $5.40^{* * *}$ & 1.60 & $5.10^{* * *}$ & 5.14 & $5.96^{* * * *}$ \\
\hline Residual & 48 & 4.42 & 2.51 & 6.91 & & & \\
\hline \multicolumn{8}{|l|}{4 to 14 August } \\
\hline Tidal phase (A) & 1 & 0.01 & $0.02 \mathrm{~ns}$ & 0.06 & $0.25 \mathrm{~ns}$ & 0.03 & $0.12 \mathrm{~ns}$ \\
\hline Light (B) & 1 & 5.59 & $19.2^{* * * *}$ & 2.05 & $8.62^{* *}$ & 4.91 & $17.8^{* * * *}$ \\
\hline Depth (C) & 1 & 0.95 & $3.28 \mathrm{~ns}$ & 0.22 & $0.91 \mathrm{~ns}$ & 0.15 & $0.54 \mathrm{~ns}$ \\
\hline $\mathrm{A} \times \mathrm{B}$ & 1 & 0.09 & $0.32 \mathrm{~ns}$ & 1.99 & $8.38^{* *}$ & 0.36 & $1.29 \mathrm{~ns}$ \\
\hline $\mathrm{A} \times \mathrm{C}$ & 1 & 0.11 & $0.36 \mathrm{~ns}$ & 0.00 & $0.02 \mathrm{~ns}$ & 0.03 & $0.12 \mathrm{~ns}$ \\
\hline $\mathrm{B} \times \mathrm{C}$ & 1 & 0.00 & $0.02 \mathrm{~ns}$ & 0.21 & $0.89 \mathrm{~ns}$ & 0.53 & $1.91 \mathrm{~ns}$ \\
\hline $\mathrm{A} \times \mathrm{B} \times \mathrm{C}$ & 1 & 0.00 & $0.00 \mathrm{~ns}$ & 0.01 & $0.03 \mathrm{~ns}$ & 0.36 & $1.32 \mathrm{~ns}$ \\
\hline Residual & 136 & 39.50 & 32.31 & 37.43 & & & \\
\hline
\end{tabular}

Table 2. Carcinus maenas, field experiment. Summary of SNK-analyses testing for differences in larval abundances collected at different light-tidal phases, during Sampling Periods 1 (4 to 7 August) and 2 (11 to 14 August). The combination between light and tidal phases when the highest abundance of larvae was collected is noted to the left, and combinations that are underlined do not differ significantly $(\mathrm{p}<0.05)$. Light phases were night $(\mathrm{Ni})$, dawn $(\mathrm{Dw})$, day (Dy) and evening (Ev). Tidal phases were ebb (E) and flood (F). '-' denotes that no larvae were collected in the particular light-tidal phase. In Sampling Period 1, there were no significant differences in the abundance of Zoeae 2 to 4 and megalopae between surface and bottom

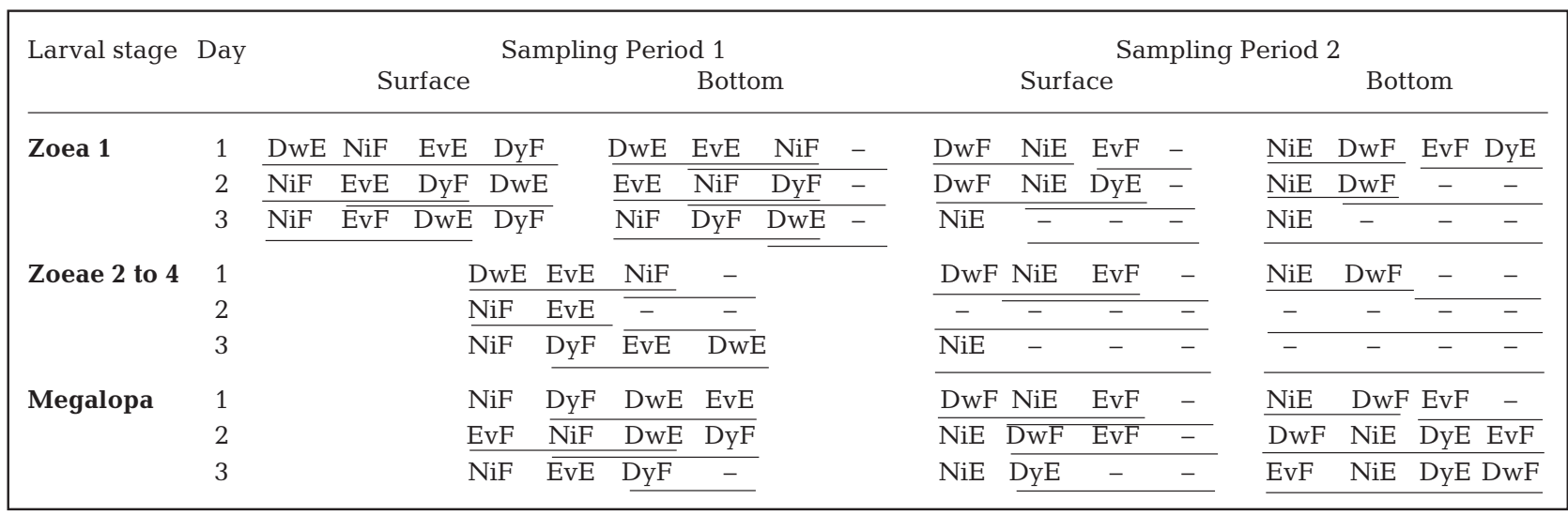


(Figs. 2 \& 3). Densities of different zoeal stages decreased by a factor of almost 10 from the first to the fourth stages (average concentration, in ind. $\mathrm{m}^{-3} \pm 1 \mathrm{SE}$, were $0.69 \pm 0.110,0.25 \pm 0.066,0.16 \pm 0.050$ and $0.08 \pm$ 0.034 , for Zoeae 1, 2, 3 and 4, respectively), whereas megalopal densities were similar to densities of first zoea $\left(0.67 \pm 0.117\right.$ ind $\left.\mathrm{m}^{-3}\right)$. The different larval stages showed a surprisingly similar vertical and temporal pattern. The highest densities of all larval stages were consistently collected at low light conditions, irrespective of tidal phase, suggesting that light, but not the tides, affects the distribution of shore crab larvae. Few and no consistent differences were found between sampling depths, and significant differences were only detected during night samples when peak densities occurred at 1 of the depths.

\section{First-stage zoea}

Densities of first-stage zoea showed a variable temporal pattern, but, invariably, peak densities occurred at low light conditions during both sampling periods, irrespective of tidal phase. Additionally, the average density of first zoea was very similar during ebb and flood tides, and at the 2 sampling depths (Figs. $2 \& 4$ a). In the first sampling period, densities of first zoea were significantly higher during low light conditions in both surface and bottom samples, but peak densities occurred during different tidal-light phases at different depths and days causing a significant 3-way interaction effect (Fig. 2a, Table 1; see Table 2 for results of SNKtests). Some of the interaction effect was likely caused by the progressive change in light conditions at each tidal phase over the $3 \mathrm{~d}$ period. For example, dawn samples were collected in complete darkness the first day, but at twilight the following days. The only significant differences between the 2 sampling depths occurred at night-flood tides and at evening-ebb tides on the second and third day, respectively, when peak numbers of first zoea were collected in the surface samples (Fig. 2a; SNK-test $\mathrm{p}<0.05$ ). In the second sampling period, when the opposite light-tidal phases were sampled, the highest densities of first zoea were still collected during low light conditions at both depths, but again at different light-tidal phases, days and depths, causing a significant 3-way interaction effect (Fig. 2b, Table 1; see Table 2 for results of SNK-tests). Again, the gradual shift in light conditions during each tidal phase sampled likely contributes to the interaction effect. Significant differences between the 2 depths were only detected during peak events of first zoea occurring at night-ebb tides the first and the third day, when significantly higher densities were collected at the bottom and surface, respectively (Fig. 2b; SNK-test $p<0.05$ ).
The complementary analyses using data from both sampling periods and separating the effect of tides and light showed a significant effect of light condition, but no effect of tidal phase or sampling depth (Table 1, Fig. 4a). The effect of light on zoeal abundance was further supported in the linear regression analyses, where a significant negative relation $(p<0.01)$ was found between the light intensity (PAR) and densities of first zoea, although the regression explained only a small percentage of the variation $\left(\mathrm{r}^{2}=0.05\right)$.

\section{Second- to fourth-stage zoeae}

The temporal pattern of Zoeal Stages 2 to 4 was very similar to the pattern of first zoea with low densities during the day and peak numbers occurring mainly at night (Fig. 2). Densities of the second, third
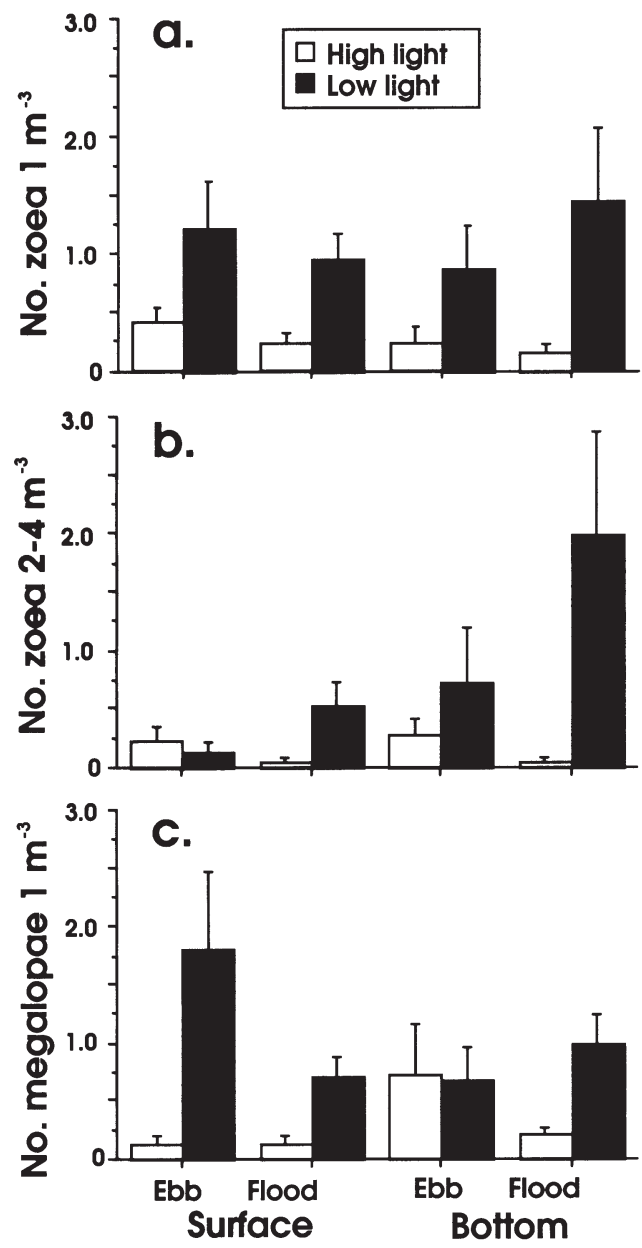

Fig. 4. Carcinus maenas. Mean number (+1 SE) of (a) first zoea, (b) second to fourth zoeae and (c) megalopa from surface and bottom samples collected during ebb and flood tides during high and low light conditions, using data from both sampling periods 
and fourth zoeae correlated significantly with densities of the first zoea (correlation coefficient, r, of 0.69 , 0.75 and 0.55 , for zoeae 2 to $4, \mathrm{p}<0.001$ in all cases). In contrast to the abundance of first zoea, which on average was similar at both sampling depths, peak densities of later zoeal stages occurred mainly in bottom samples (Figs. $2 \& 4$ b). In the first sampling period, densities of second to fourth zoeae were significantly higher during low light conditions, but at different tidal phases on different days, causing a significant interaction effect between tidal-light phase and day (Fig. 2a, Table 1; see Table 2 for results of SNK-tests). No significant differences were found between the sampling depths at any time. In the second sampling period, fewer later-stage zoeae were collected, but these were still concentrated in the dark part of the day (no Zoeal Stages 2 to 4 were found during day-ebb tides), even though the opposite lighttidal phases were sampled. However, peak densities
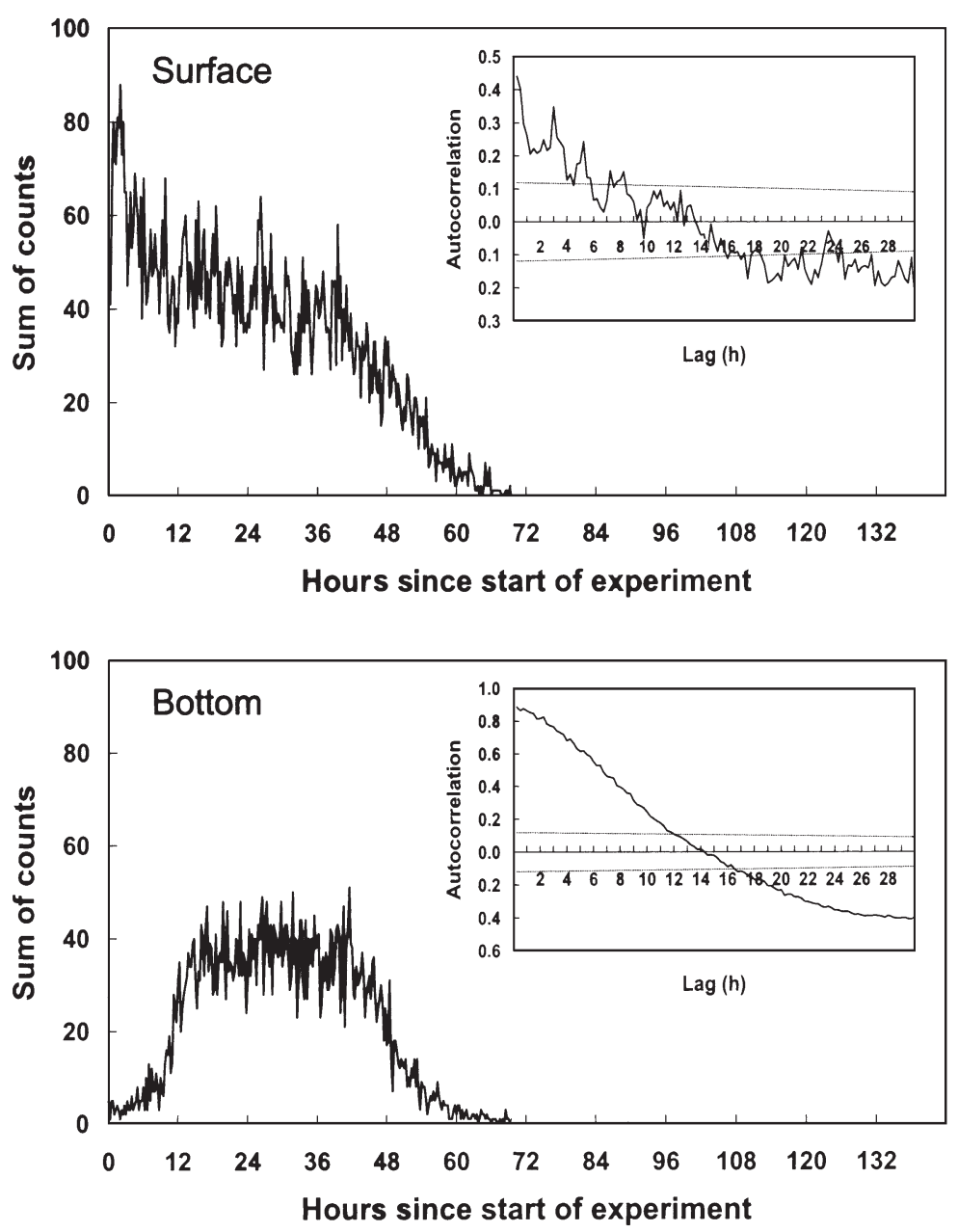

Fig. 5. Carcinus maenas first zoea, Trial 3. Total number of larvae counted in grid cells, at 15 min intervals, below the surface and above the bottom of the experimental column occurred during different tidal phases at different depths and days, again causing a significant 3-way interaction effect (Fig. 2b, Table 1; see Table 2 for results of SNK-tests). The only significant differences between the 2 sampling depths occurred at nigh-ebb tides the first day, when peak numbers of second to fourth zoea were collected in the bottom samples (Fig. 2b; SNK-test $\mathrm{p}<0.05$ ).

The analysis where data from both sampling periods were used showed a significant main effect of light, no main effect of tides or depth, but a significant interaction effect between tides and light caused by significantly higher zoeal densities in night flood-tide samples compared to day and ebb samples (Fig. 4b, Table 1; SNK-test $\mathrm{p}<0.05)$. This interaction effect was mainly a result of a peak density of zoeae 2 to 4 occurring in the night-flood samples from 7 August, and did not represent a general trend (Fig. 2). The relationship between light intensity (PAR) and densities of second to fourth zoeae was similar to that of first zoea showing a negative correlation, but the regression was not significant, although the $p$-value was suspiciously low $(p=0.08)$.

\section{Megalopa}

Similarly to the zoeal stages, low numbers of megalopae were collected during daylight, and peak densities consistently occurred during low light conditions at both depths, irrespective of tidal phase (Fig. 3). In contrast to later-stage zoeae, which peaked mainly in bottom samples at night, peak densities of megalopae occurred mainly in surface samples at night (Fig. 4c), and no significant correlation was found between the number of second to fourth zoeal stages and the number of megalopae. Surprisingly, the number of megalopae correlated significantly with the number of first zoeae ( $\mathrm{r}=$ $0.60, \mathrm{p}<0.001)$. In the first sampling period, densities of megalopae were significantly higher during low light conditions but at different tidal phases on different days. Therefore, a significant interaction effect was evident between light-tidal phase and day (Fig. 3a, Table 1; see Table 2 for results of SNK-tests). No significant differences were found between the sampling depths at any time (Table 1). In the second sampling period, when the opposite light-tidal phases were sampled, the highest densities of megalopae were still collected during low light conditions at both depths, and peak 
densities again occurred during different tidal phases at different depths and days, with a significant 3-way interaction effect (Fig. 4b, Table 1 ; see Table 2 for results of SNK-tests). Significantly higher densities of megalopae were collected in bottom samples compared to surface samples at night-ebb and dawn-flood tides the first day, whereas the opposite depth distribution was found the last 2 days when significantly higher densities were collected at the surface during night-ebb tides. No other significant differences were detected between the 2 sampling depths (Fig. 4b; SNK-test $p>0.05$ ).

Similarly to first zoea, the complementary analyses using data from both sampling periods showed a significant effect of light condition, but no effect of tidal phase or sampling depth (Fig. 4c, Table 1). The importance of light on megalopal abundance was further supported by the linear regression analyses, where a significant negative relation between light intensity (PAR) and densities of megalopae was found $(\mathrm{p}<0.01)$, although the regression explained only a smaller percentage of the variation $\left(r^{2}=0.07\right)$.

\section{Laboratory experiment - endogenous rhythms in first zoea}

We found very little evidence of endogenous vertical migration rhythm in laboratoryhatched first zoeae from the Swedish west coast. The larvae from 8 of the 10 females appeared not to migrate vertically in synchrony at constant darkness, and the auto-correlation analyses did not indicate any rhythm of either circa-tidal or circa-diel periodicity (see Fig. 5 for a representative example) Only in Trial 1 did the number of larvae cycle with a circa-tidal periodicity of 12 to $13 \mathrm{~h}$, but this was only clearly recognised at the surface (Fig. 6). However, in this trial, an increase of number of larvae at the surface was usually paralleled by a decrease at the bottom. It is possible that the gap on the bottom data series, which resulted from a bad connection of power cables, obscures a basic pattern of circa-tidal periodicity. In Trial 4, autocorrelation of the surface series peaked at a time lag between 14 and $16 \mathrm{~h}$, but no such result was observed in the bottom series.

\section{DISCUSSION}

The field-sampling program collected variable densities of all zoeal stages and mega- lopae of Carcinus maenas in both surface and bottom samples. However, the average abundance of zoeae decreased from the first to the fourth stage by an order of magnitude, whereas densities of megalopae were similar to that of the first zoea. This pattern in abundance indicates an offshore/onshore transportation of larvae during development, suggesting a behavioural component that changes during ontogeny and causes non-random dispersal of the larval stages. Differences in development times between larval stages could not have caused this pattern in abundance since development times are similar for the different zoeal stages and in megalopae at constant temperatures (Dawirs 1985, Mohamedeen \& Hartnoll 1989, Nagaraj 1993). Although the field sampling was temporally limited, therefore restricting our ability to draw general conclusions, the field data demonstrated a persistent nocturnal pattern in larval abundance. Hence, we argue that both zoeal and megalopal stages of Swedish shore
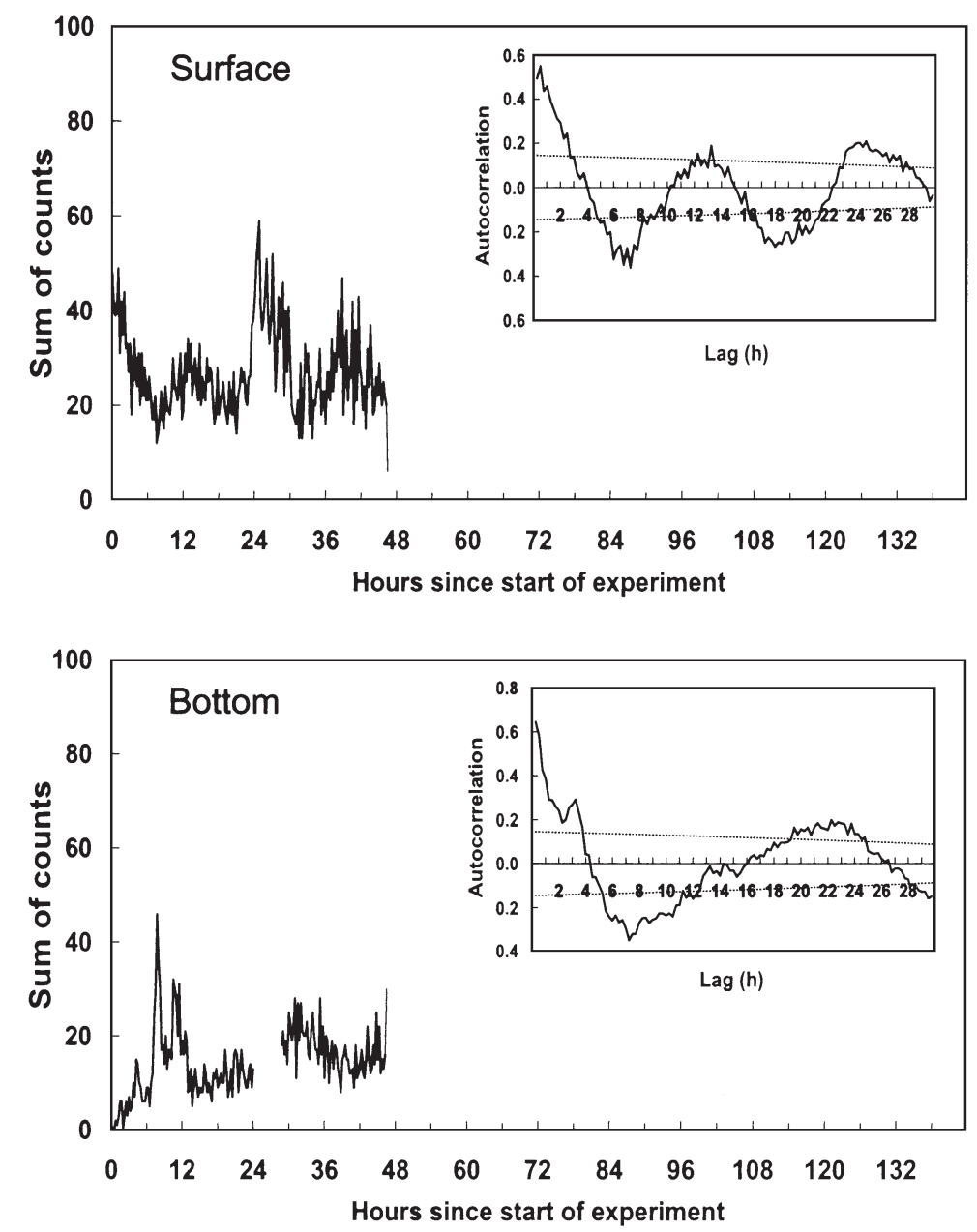

Fig. 6. Carcinus maenas first zoea, Trial 1. Total number of larvae counted in grid cells, at 15 min intervals, below the surface and above the bottom of the experimental colum 
crabs migrate vertically in response to exogenous cues, and that light intensity, not the tidal phase, is the critical factor in this micro-tidal system.

The present study did not find any significant effects of phase of tide on vertical distribution in the field for any of the stages investigated, in spite of a clear tidal change in water level in the order of 0.2 to $0.5 \mathrm{~m}$. These results contrast with the clear tide-related distribution described for Carcinus maenas larvae in meso-tidal estuaries and coastal areas in Portugal (Queiroga et al. 1997, Queiroga 1998) and the British Isles (Zeng \& Naylor 1996a,b). In the laboratory experiments designed to test for an endogenous component of vertical migration behaviour in C. maenas first zoea, a possible indication of a circa-tidal rhythm was found in only 1 case out of 10 . This result also contrasts to similar experiments performed in meso-tidal areas, where first zoeae demonstrated a clear circa-tidal rhythm in constant laboratory conditions (Zeng \& Naylor 1996a,d, Duchêne \& Queiroga 2001). In the present experiments, there was rarely any correspondence between number of larvae at the surface and bottom of the experimental chamber; that is, when numbers decreased at the surface they did not consistently increase at bottom, and vice versa. This is also contrary to the data collected by Zeng \& Naylor (1996a), which showed clear and complementary variations of number of larvae at the surface and bottom. These observations lead us to deduct that $C$. maenas larvae from the Gullmarsfjord do not display an endogenous vertical migration rhythm synchronised with the tide. The lack of a tidal component in the abundance of megalopae is also consistent with recent findings that settlement of Swedish C. maenas megalopae on artificial settlement collectors was not affected by the tidal phase (P.-O. Moksnes unpubl. data). The lack of a tidal rhythm in Swedish shore crab larvae is not surprising, considering that tidal changes in water level have little effect on surface water currents in this area compared to other components of hydrological circulation (Moksnes \& Wennhage 2001). Vertical migration in phase with local tides would therefore be of little use for dispersal and recruitment. Moreover, currents associated with variations of seawater level in systems such as this are unpredictable, because they are not related to a cyclic environmental phenomenon, but with atmospheric pressure, which is an essentially stochastic factor. Therefore, the selective pressure that could lead to the development of such behaviour does not exist in this system.

Densities of all larval stages in field-collected samples were higher during the night than during the day, but did not show any consistent relationship with depth. These results indicate a nocturnal type of diel pattern in swimming behaviour and are consistent with earlier findings. Virtually all field studies on swimming behaviour of decapod larvae in coastal and oceanic waters have detected a nocturnal type of diel migration in the first and intermediate stages. These stages ascend to surface or subsurface layers during late afternoon and dusk and descend somewhere during the night or at dawn, e.g. Cancer magister (Hobbs \& Botsford 1992), Cancer spp., Randalia ornata (Shanks 1986) and Panulirus cygnus (Rimmer \& Phillips 1979). The lack of a diel pattern in the depth distribution of the zoeal stages in the present study could be explained if the zoeae either migrated deeper than $10 \mathrm{~m}$ (below the pycnocline) during the day and were therefore not brought up into the shallow bay where samples were taken, or if they concentrated very close to the bottom, just below the $9 \mathrm{~m}$ sample depth, so that very few were sampled during day hours. Since no diel rhythm was detected in the laboratory experiments with first zoea Carcinus maenas, this diel pattern of vertical migration is likely controlled by exogenous cues.

The nocturnal type of diel abundance pattern of Carcinus maenas megalopae suggested by the field data is also in accordance with other studies of decapod larvae. A general rule within this group seems to be that the phasing and the extent of the migration change during the course of ontogenic development, and that patterns of vertical migration of the competent stage are more variable than in the zoeal stages. Different temporal patterns of abundance have been found for the same species in different studies (Smyth 1980, Maris 1990) and there is indication that behaviour changes with age within the megalopal stage (Shanks 1986, Hobbs \& Botsford 1992). Ontogenic displacements to deeper waters have also been described for a number of species (Lindley 1986, Queiroga 1996). Moreover, day light levels inhibit swimming of megalopae of estuarine crabs as they leave shelf waters and enter these systems (Forward \& Rittschof 1994). The nocturnal increase in megalopae abundance found in the present study and the lack of a diel pattern in their depth distribution are consistent with recent findings that late-stage shore crab megalopae cling to benthic habitats during daylight and leave them at dusk in order to swim in surface water during the night (P.-O. Moksnes unpubl. data). Similarly to the zoeae, the diel pattern found for the megalopal stage was also likely controlled by exogenous cues, since swimming behaviour in late-stage C. maenas megalopae from mesotidal areas appears not to be controlled by their endogenous clock (Zeng \& Naylor 1996b).

Earlier laboratory studies that showed positive phototaxis in crab larvae (reviewed by Sulkin 1984) were flawed because narrow light beams were used (Forward et al. 1984, Forward 1988). When tested with 
lighting apparatuses that simulate the natural angular light distribution, most zooplankton, including decapod larvae, show negative phototaxis at high light intensities, which is supported by the fact that they are more common in surface waters at night. The observed negative correlation between light intensity data and concentration of first zoeae and megalopae also supports the conclusion of a migration towards the surface during the night.

A nocturnal pattern of activity could be involved in a cross-shelf dispersal mechanism for shore crabs. Among the proposed physical mechanisms that may transport marine larvae across the shelf (reviewed by Shanks 1995), the only predictable current-generating component in the Swedish Skagerrak and Kattegat appears to be the sea-land breeze, i.e. the change in wind direction associated with the heating and cooling of land during the day and night, respectively. Sea and land breezes may reach over $30 \mathrm{~km}$ off shore (Shanks 1995), and the resulting wind drift current has been proposed as a possible cross-shelf dispersal mechanism (Shanks 1986). According to this hypothesis, zoea larvae would use light as a cue to enter the surface after sunset, when the sea breeze (onshore) is decreasing and the land breeze (offshore) is about to start. By swimming in the surface area during the night and descending at dawn, they may experience an offshore horizontal transport. The opposite migration pattern by megalopae would subsequently result in an onshore transport. The present study demonstrated a nocturnal diel migration for the zoeal stages consistent with this theory, but the same diel pattern was found for megalopae, contrary to the predictions. However, the inconsistent result could possibly be explained if megalopae in earlier development stages, which should be found more offshore, swim in the surface during the day. As they grow older and/or reach chemical and physical cues of land and nursery areas, they could switch behaviour and swim in the neuston at night, possibly to avoid visual predators and/or premature stranding (as suggested by Zeng \& Naylor 1997). In support of these suggestions, Cancer magister megalopae appear to change their diel vertical migration behaviour during ontogeny (Hobbs \& Botsford 1992, Shanks 1986). Further studies are necessary to assess these hypotheses.

Zeng \& Naylor (1996d) have shown that the vertical migration behaviour of Carcinus maenas first zoea is genetically determined. When immature crabs from Wales were kept in the laboratory in constant conditions and left to mature, copulate and hatch their larvae, the zoeae, which were never subjected to a natural or artificial cycle of hydrostatic pressure, displayed a remarkable pattern of vertical migration. The vertical position of the larvae in the test chamber changed with a period of 12 to $13 \mathrm{~h}$. In the present study, we found very little evidence of an endogenous circa-tidal swimming behaviour in Zoea 1, although we had mimicked the experimental set-up of Zeng \& Naylor (1996d). This result and the lack of a tidal pattern in field-collected zoeae indicate that larvae of $C$. maenas from the Skagerrak lack this behaviour and, hence, that these populations are reproductively isolated from the British Isles populations. These results therefore suggest that Carcinus larvae are not continuously exchanged among sub-populations between the British Isles and the Skagerrak-Kattegat, and/or that the 2 meta-populations have been isolated from each other in the past and that behavioural adaptations to different tidal environments would give the larvae low fitness if they ventured into the other system. There is some evidence of a physical isolation mechanism that may limit the exchange of larvae between the Skagerrak-Kattegat and the North Sea. Recent studies indicate that small gyres formed in the Skagerrak and Kattegat can block the inflow of surface waters from the southern part of the North Sea into the SkagerrakKattegat (Danielssen et al. 1991, 1997), and have been suggested to retain Norwegian lobster larvae (Nephrops norvegicus) along the Swedish west coast (Øresland 1998). However, glass-eels Anguilla anguilla immigrate from the North Sea into the Skagerrak and Kattegat area during late winter (Westerberg 1998), and the recently introduced bivalve Ensis americanus has dispersed from west Denmark to west Sweden, presumably by larval drift (Armonies \& Reise 1999), indicating that significant exchange of larvae may occur between the 2 systems. Further studies are needed to confirm genetic differences between Swedish and British shore crabs, and to investigate potential physical and biological isolation mechanisms in these systems.

Acknowledgements. The authors wish to express their thanks to Ana Coelho, Luisa Fontes, Nelson Abrantes and Suzana Alarico, students of the Department of Biology of the University of Aveiro, for their long hours spent playing back and analysing tapes. We would also like to thank the staff at Kristineberg Marine Research Station for providing excellent facilities, Hans Olsson for helpful technical support, and Håkan Wennhage for generously lending us IR-video equipment. A European Union grant, under the Training and Mobility of Researchers - Access to Large Scale Facilities programme, supported travelling, subsistence and research expenses of H.Q. and S.M. at the Kristineberg Marine Research Station.

\section{LITERATURE CITED}

Andersson L, Rahm L (1985) Heat balance of a shallow cove. Estuar Coast Shelf Sci 23:705-724

Armonies W, Reise K (1999) On the population development of the introduced razor clam Ensis americanus near the island of Sylt (North Sea). Helgol Meeresunters 52:291-300 Boehlert GW, Mundy BC (1988) Roles of behavioural and 
physical factors in larval and juvenile fish recruitment to estuarine nursery areas. Am Fish Soc Symp 3:51-67

Bingham BL, Young CM (1991) Larval behaviour of the ascidian Ecteinascidia turbinata Herdman: an in situ experimental study of the effects of swimming on dispersal. J Exp Mar Biol Ecol 145:189-204

Chia FS, Buckland-Nicks J, Young CM (1984) Locomotion of marine invertebrate larvae: a review. Can J Zool 62: $1205-1222$

Cronin TW, Forward RB Jr (1979) Tidal vertical migration: an endogeneous rhythm in estuarine crab larvae. Science 205:1020-1022

Cronin TW, Forward RB Jr (1982) Tidally timed behaviour: effects on larval distributions in estuaries. In: Kennedy VS (ed) Estuarine comparisons. Academic Press, New York, p 505-520

Danielssen DS, Davidsson L, Edler L, Fogelqvist E and 6 others (1991) Skagex: some preliminary results. ICES-CM C: $2: 14$

Danielssen DS, Edler L, Fonselius SH, Hernroth L, Ostrowski M, Svendsen E, Talpsepp L (1997) Oceanographic variability in the Skagerrak and northern Kattegat, May-June, 1990. ICES J Mar Sci 54:753-773

Dawirs RR (1985) Temperature and larval development of Carcinus maenas (Decapoda) in the laboratory; prediction of larval dynamics in the sea. Mar Ecol Prog Ser 24:297-302

Duchêne JC, Queiroga H (2001) Use of an intelligent CCD camera for the study of endogenous vertical migration rhythms in first zoeae of the crab Carcinus maenas. Mar Biol 139:901-909

Eriksson S, Edlund AM (1977) On the ecological energetics of 0-group Carcinus maenas (L.) from shallow sandy bottom in Gullmar fjord, Sweden. J Exp Mar Biol Ecol 30:233-248

Fofonoff ND, Millard RC Jr (1983) Algorithms for computation of fundamental properties of sea water. UNESCO Tech Pap Mar Sci No 44

Fortier L, Leggett WC (1983) Vertical migrations and transport of larval fish in a partially mixed estuary. Can J Fish Aquat Sci 40(10):1543-1555

Forward RB Jr (1976) Light and diurnal vertical migration: photobehaviour and photophysiology of plankton. In: Smith KC (ed) Photochemical and photobiological reviews, Vol 1. Plenum Press, New York, p 157-209

Forward RB Jr (1988) Diel vertical migration: Zooplankton photobiology and behaviour. Oceanogr Mar Biol Annu Rev 26:361-393

Forward RB Jr, Costlow J (1974) The ontogeny of phototaxis by larvae of the crab Rhithropanopeus harrisii. Mar Biol $26: 27-33$

Forward RB Jr, Rittschof D (1994) Photoresponses of crab megalopae in offshore and estuarine waters: implications for transport. J Exp Mar Biol Ecol 182:183-192

Forward RB Jr, Cronin TW, Stearns DE (1984) Control of diel vertical migration: photoresponses of a larval crustacean. Limnol Oceanogr 29:146-154

Hobbs RC, Botsford LW (1992) Diel vertical migration and timing to metamorphosis of larvae of the Dungeness crab Cancer magister. Mar Biol 112:417-428

Lindley JA (1986) Vertical distributions of decapod crustacean larvae and pelagic post-larvae over Great Sole Bank (Celtic Sea) in June 1983. Mar Biol 90:545-549

Lindley JA (1987) Continuous plankton records: the geographical distribution and seasonal cycles of decapod crustacean larvae and pelagic post-larvae in the northeastern Atlantic Ocean and the North Sea, 1981-3. J Mar Biol Assoc UK 67:145-167

Maris RC (1990) Dispersal-recruitment mechanisms of Calli- nectes sapidus Rathbun involving larval and postlarval patterns of diurnal vertical distribution in the vicinity of the Chesapeake Bay, Virginia. Bull Mar Sci 46:247

Mohamedeen H, Hartnoll RG (1989) Larval and post-larval growth of individually reared specimens of the common shore crab Carcinus maenas (L.). J Exp Mar Biol Ecol 134: $1-24$

Moksnes PO, Wennhage H (2001) Methods for estimating decapod larval supply and settlement: importance of larval behavior and development stage. Mar Ecol Prog Ser 209:257-273

Nagaraj M (1993) Combined effects of temperature and salinity on the zoeal development of the green crab, Carcinus maenas (Linnaeus, 1758) (Decapoda: Portunidae). Sci Mar 57(1):1-8

Norcross BL, Shaw RF (1984) Oceanic and estuarine transport of fish eggs and larvae: a review. Trans Am Fish Soc 113: 153-165

Øresland V (1998) Occurrence, transport and retention mechanisms of Norway lobster larvae in Skagerrak and Kattegat. Medd Havsfiskelab Lysekil No 328:7-17

Phil L, Rosenberg R (1982) Production, abundance and biomass of mobile epibenthic marine fauna in shallow waters, western Sweden. J Exp Mar Biol Ecol 57:273-301

Phillips BF (1981) The circulation of the southeastern Indian Ocean and the planktonic life cycle of the western rock lobster. Oceanogr Mar Biol Annu Rev 19:11-39

Queiroga H (1995) Processos de dispersão e recrutamento das larvas do caranguejo Carcinus maenas (L.) na Ria de Aveiro. PhD thesis, Universidade de Aveiro, Aveiro, Portugal

Queiroga H (1996) Distribution and drift of the crab Carcinus maenas (L.) (Decapoda, Portunidae) larvae over the continental shelf off northern Portugal in April 1991. J Plankton Res 18(11):1981-2000

Queiroga H (1998) Vertical migration and selective tidal stream transport in the megalopa of the crab Carcinus maenas. Hydrobiology 375/376:137-149

Queiroga H, Costlow JD Jr, Moreira MH (1994) Larval abundance patterns of Carcinus maenas (Decapoda, Brachyura) in Canal de Mira (Ria de Aveiro, Portugal). Mar Ecol Prog Ser 111:63-72

Queiroga H, Costlow JD Jr, Moreira MH (1997) Vertical migration of the crab Carcinus maenas first zoea in an estuary: implications for tidal stream transport. Mar Ecol Prog Ser 149:121-132

Rees CB (1955) Continuous plankton records: the decapod larvae in the North Sea, 1950-51. Hull Bull Mar Ecol $\operatorname{IV}(29): 69-80$

Rice AL, Ingle RW (1975) The larval development of Carcinus maenas (L.) and C. mediterraneus Czerniavsky (Crustacea, Brachyura, Portunidae) reared in the laboratory. Bull Br Mus (Nat Hist) Zool 28(3):103-120

Rimmer DW, Phillips BF (1979) Diurnal migration and vertical distribution of phyllosoma larvae of the Western rock lobster Panulirus cygnus. Mar Biol 54:109-124

Roff JC, Fanning LP, Stasko AB (1986) Distribution and association of larval crabs (Decapoda: Brachyura) on the Scotian Shelf. Can J Fish Aquat Sci 43:587-599

Shanks AL (1986) Vertical migration and cross-shelf dispersal of larval Cancer spp. and Randalia ornata (Crustacea: Brachyura) off the coast of southern California. Mar Biol 92:189-199

Shanks AL (1995) Mechanisms of cross-shelf dispersal of larval invertebrates and fish. In: McEdward L (ed) Biology of marine invertebrate larvae. CRC Press, Boca Raton, FL, p 323-367 
Smyth PO (1980) Callinectes (Decapoda: Portunidae) larvae in the middle Atlantic Bight, 1975-77. Fish Bull 78: 251-265

Söderkvist J (1997) Water exchange in a shallow bay. MSc thesis, Göteborg University

Sokal RR, Rohlf FJ (1969) Biometry: the principles and practice of statistics in biological research. WH Freeman, San Francisco

Sulkin SD (1984) Behavioural basis of depth regulation in the larvae of brachyuran crabs. Mar Ecol Prog Ser 15: 181-205

Svansson A (1984) Hydrographic of the Gullmarsfjord. Institute of Hydrographic Research, Göteborg Ser 23:1-21

Udekem d'Acoz C (1999) Inventaire et distribution des crustacés décapodes de l'Atlantique nord-orientale, de la Méditerranée et des eaux douces continentales adjacentes au nord de $25^{\circ} \mathrm{N}$. Patrimoines Naturels, Vol 40, Muséum National d'Histoire Naturelle, Service du Patrimoine Naturel, Paris

Westerberg H (1998) The migration of glass-eel and elvers in the Skagerrak and the Kategatt. ICES-CM N:11

Willis BL, Oliver JK (1990) Direct tracking of coral larvae: implications for dispersal studies of planktonic larvae in topographically complex environments. Ophelia 32: 145-162

Young CM (1995) Behaviour and locomotion during the dis-

Editorial responsibility: Otto Kinne (Editor),

Oldendorf/Luhe, Germany persal phase of larval life. In: McEdward L (ed) Biology of marine invertebrate larvae. CPR Press, Boca Raton, FL, p 249-277

Young CM, Chia FS (1987) Abundance and distribution of pelagic larvae as influenced by predation, behavior, and hydrographic factors. In: Giese AC, Pearse JS, Pearse VV (eds) Reproduction of marine invertebrates. Blackwell Scientific, Palo Alto, p 385-463

Zeng C, Naylor E (1996a) Endogenous tidal rhythms of vertical migration in field collected zoea-1 larvae of the shore crab Carcinus maenas: implications for ebb tide offshore dispersion. Mar Ecol Prog Ser 132:71-82

Zeng C, Naylor E (1996b) Occurrence in coastal waters and endogenous tidal swimming rhythms of late megalopae of the shore crabs Carcinus maenas: implications for onshore recruitment. Mar Ecol Prog Ser 136:69-79

Zeng C, Naylor E (1996c) Synchronization of endogenous tidal vertical migration rhythms in laboratory-hatched larvae of the crab Carcinus maenas. J Exp Mar Biol Ecol 198:269-289

Zeng C, Naylor E (1996d) Heritability of circa-tidal vertical migration rhythms in zoea larvae of the crab Carcinus maenas (L.). J Exp Mar Biol Ecol 202:239-257

Zeng C, Naylor E (1997) Rhythms of larval release in the shore crab Carcinus maenas (Decapoda: Brachyura). J Mar Biol Assoc UK 77:451-461

Submitted: October 24, 2001; Accepted: March 7, 2002 Proofs received from author(s): June 28, 2002 